\title{
Methane in surface waters of the Arabian Sea
}

\author{
H.W. Bange, R. Ramesh, ${ }^{1}$ S. Rapsomanikis, ${ }^{2}$ and M.O. Andreae
}

Biogeochemistry Department, Max Planck Institute for Chemistry, Mainz, Germany

\begin{abstract}
More than 2000 measurements of atmospheric and dissolved methane $\left(\mathrm{CH}_{4}\right)$ were performed in the central and northwestern Arabian Sea as part of the German JGOFS Arabian Sea Process Study during three cruises in March, May/June, and June/July 1997. Mean $\mathrm{CH}_{4}$ saturations in the surface waters of the central Arabian Sea were in the range of 103-107\%. Significantly enhanced saturations were observed in the coastal upwelling area at the coast of Oman (up to $156 \%$ ) and in an upwelling filament (up to $145 \%$ ). The $\mathrm{CH}_{4}$ surface concentrations in the upwelling area were negatively correlated to sea surface temperatures. Areaweighted, seasonally adjusted estimates of the sea-air fluxes of $\mathrm{CH}_{4}$ gave annual emissions from the Arabian Sea of 11-20 $\mathrm{Gg} \mathrm{CH}$, suggesting that previously reported very high surface $\mathrm{CH}_{4}$ concentrations might be atypical owing to the interannual variability of the Arabian Sea and that the emissions derived from them are probably overestimates.
\end{abstract}

\section{Introduction}

Atmospheric methane $\left(\mathrm{CH}_{4}\right)$ is a greenhouse gas and plays an important role in both tropospheric and stratospheric chemistry [Cicerone and Oremland, 1988; Lelieveld et al., 1993]. Therefore, it is necessary to evaluate the contributions of natural and anthropogenic sources to estimate the global budget of atmospheric $\mathrm{CH}_{4}$. The world's oceans, as a natural source of $\mathrm{CH}_{4}$, play only a minor role in the global budget of atmospheric $\mathrm{CH}_{4}$ [Hein et al., 1997; Matthews, 1994]. However, recent global estimates of the oceanic $\mathrm{CH}_{4}$ emissions differ considerably and range from 0.4 to $15 \mathrm{Tg} \mathrm{CH}_{4} \mathrm{yr}^{-1}$ [Bange et al., 1994; Bates et $a l ., 1996]$, indicating a need for further study.

Biologically productive regions (e.g., shelf areas) which cover only about $16 \%$ of the world's ocean area appear to be responsible for about $75 \%$ of the oceanic $\mathrm{CH}_{4}$ emissions [Bange et al., 1994]. The Arabian Sea has only a small portion of shelf areas; however, it is one of the most biologically productive regions of the world's oceans. Since the study of Owens et al. [1991] in 1986, it was speculated that the Arabian Sea, especially its upwelling-dominated northwestern part, represents a hot spot for $\mathrm{CH}_{4}$ emissions, making a substantial contribution to the global budget of oceanic emissions.

Here we present more than 2000 measurements of atmospheric and dissolved $\mathrm{CH}_{4}$ in the Arabian Sea during the intermonsoon

\footnotetext{
Institute for Ocean Management, Anna University, Chennai, India.

${ }^{2}$ now at: Laboratory of Atmospheric Pollution Science and Technology, Demokritos University of Thrace, Xanthi, Greece.
}

Copyright 1998 by the American Geophysical Union. and the southwest (SW) monsoon periods of 1997. Based on our data we present an area-weighted, seasonally adjusted $\mathrm{CH}_{4}$ flux estimate for the Arabian Sea. The three cruise legs were part of the 1997 German JGOFS (Joint Global Ocean Flux Study) Arabian Sea Process Study and took place during March (leg SO117), May/June (leg SO119), and June/July (leg SO120) on the German research vessel R/V Sonne. Legs SO117 and SO119 covered mainly the central Arabian Sea, whereas leg SO120 focused on the coastal upwelling area off the Arabian Peninsula (Figure 1).
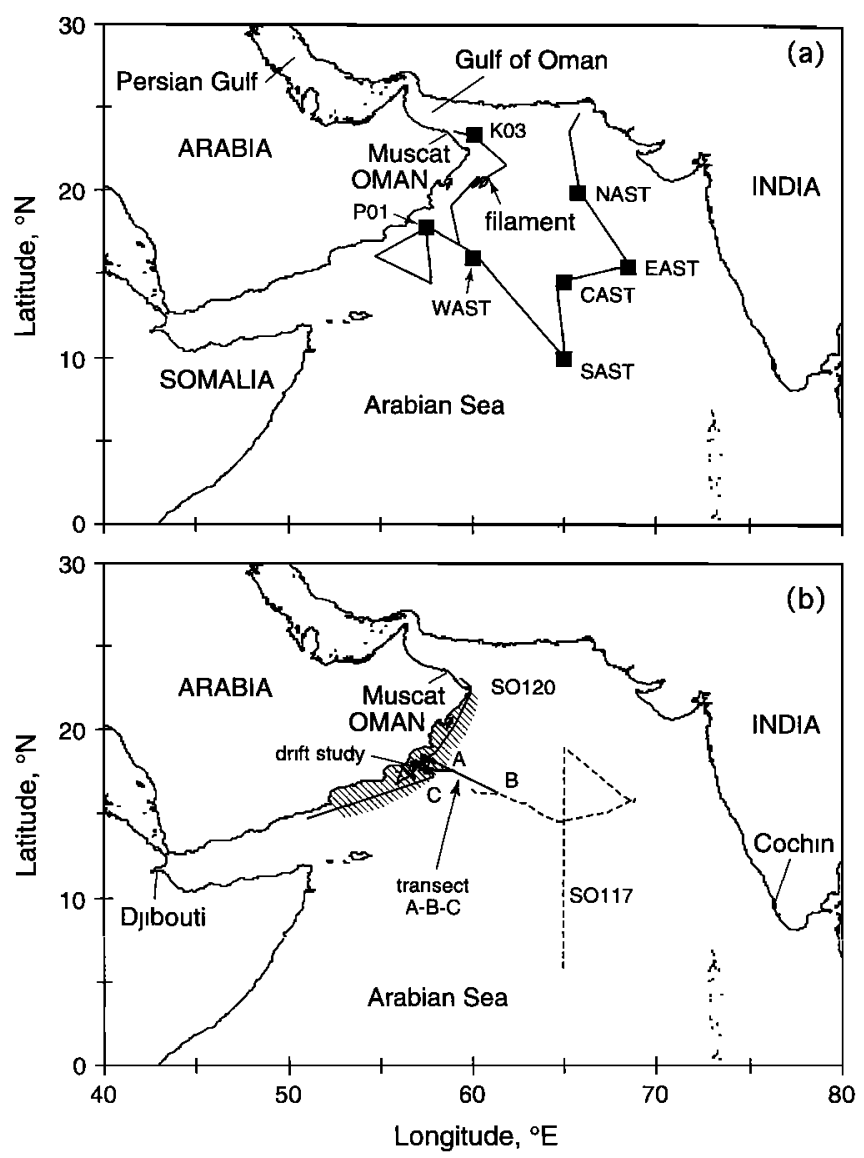

Figure 1. Cruise tracks of the R/V Sonne: (a) leg SO119, from Muscat (Oman) to Muscat, May/June 1997, (b) leg SO117 (dashed line) from Cochin (India) to Muscat, March 1997; leg SO120 (solid line) from Muscat to Djibouti, June/July 1997. The cruise tracks shown indicate the parts of the legs when $\mathrm{CH}_{4}$ was measured. The positions of some prominent stations and cruise features are marked. The hatched area indicates location of coastal upwelling during the SW monsoon. 


\section{Methods}

$\mathrm{CH}_{4}$ was determined with a gas chromatograph equipped with a flame ionization detector. Further details of the analysis system are described in Bange et al. [1994]. Seawater was pumped continuously from a depth of approximately $6.5 \mathrm{~m}$ into a shower type equilibrator developed by R. F. Weiss (Scripps Institution of Oceanography, La Jolla, CA). During the three legs, the mean differences between the water temperature at the sea chest and the continuously recorded water temperature in the equilibrator were in the range of -0.003 to $-0.05^{\circ} \mathrm{C}$. Concentrations and resulting saturation values were corrected for these differences. A series of measurements on seawater and ambient air followed by two standards $\left(1.70 \pm 2 \%\right.$ and $3.06 \pm 2 \% \mathrm{ppm} \mathrm{CH}_{4}$ in synthetic air) was repeated every $80 \mathrm{~min}$. The gravimetrically prepared gas standards were calibrated by the manufacturer (DEUSTE Steininger GmbH, Mühlhausen, Germany) against standards from the U.S. National Institute of Standards and Technology (Gaithersburg, MD). The analytical precision, calculated as the ratio of the standard deviation of the atmospheric measurements to the mean atmospheric mixing ratio, was 1.6\% (SO119, $\mathrm{SO} 120$ ). The mean relative errors of the $\mathrm{CH}_{4}$ saturation and concentration, were $2.2 \%$ and $1.6 \%$ during legs SO119 and SO120, respectively. Due to technical problems the precision and relative errors during leg SO117 were approximately twice those for the legs SO119 and SO120. Saturation values (expressed in $\%$, i.e., $100 \%=$ equilibrium) were calculated by applying the solubility equation of Wiesenburg and Guinasso [1979]. Continuous time series of seawater temperature, salinity, and wind speed were obtained from the ship's records.

\section{Results and Discussion}

The observed mean atmospheric $\mathrm{CH}_{4}$ dry mole fractions were $1.81 \pm 0.06 \mathrm{ppm}$ (March) and $1.69 \pm 0.03 \mathrm{ppm}$ (May-July). Due to the seasonal northward shift of the intertropical convergence zone, which is most pronounced during the SW monsoon in the summer months, air masses sampled during May-July were from the southern hemisphere, whereas those sampled during March were from the northern hemisphere. From 14 May until the onset of the SW monsoon on 23 May we observed a trend from 1.80 to $1.69 \mathrm{ppm} \mathrm{CH}_{4}$, indicating the transition from northern to southern hemisphere air masses. The observed atmospheric values are in agreement with $\mathrm{CH}_{4}$ measurements at the baseline monitoring stations Mace Head, Ireland and Cape Grim, Tasmania. Monthly mean values (excluding data biased by pollution events) were $1.803 \pm 0.013 \mathrm{ppm}$ (Mace Head, March 1997) and $1.693 \pm 0.003$ ppm (Cape Grim, May-July 1997). These values were calculated from the Advanced Global Atmospheric Gases Experiment (AGAGE) data set (updated version from 18 May 1998) available from the anonymous ftp site cdiac.esd.ornl.edu (subdirectory /pub/ale_gage_Agage/Agage/monthly) at the Carbon Dioxide Information Analysis Center in Oak Ridge, Tennessee.

Mean $\mathrm{CH}_{4}$ water concentrations in the central Arabian Sea were $2.09 \pm 0.30 \mathrm{nmol} \mathrm{L}^{-1}$ (March) and $1.82 \pm 0.09 \mathrm{nmol} \mathrm{L}^{-1}$ (May/June). Enhanced values (mean $2.25 \pm 0.10 \mathrm{nmol} \mathrm{L}^{-1}$, June/July) were found in the coastal upwelling area. Figure 2 shows the $\mathrm{CH}_{4}$ saturations during legs SO119 and SO120 together with the sea surface temperatures (SST) as an indicator for upwelled water masses, which could be easily identified by water temperatures lower than $30^{\circ} \mathrm{C}$ (SO119) or $28^{\circ} \mathrm{C}$ (SO120). Temperature differences up to $10^{\circ} \mathrm{C}$ between nearshore (i.e., freshly upwelled) and offshore surface waters are characteristic
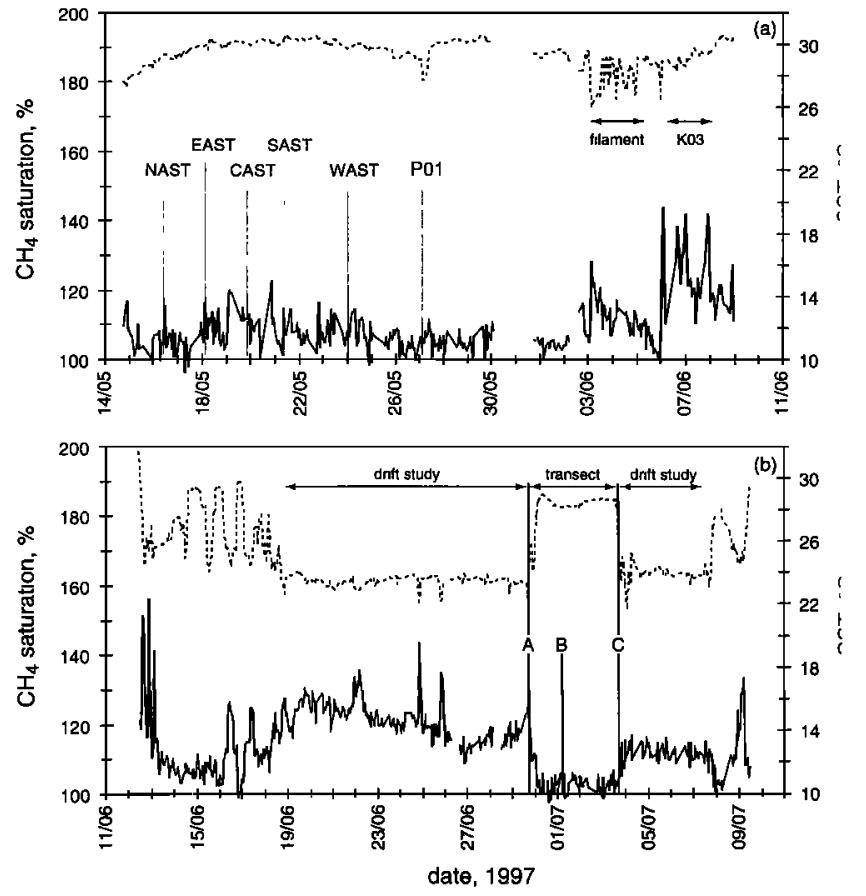

Figure 2. $\mathrm{CH}_{4}$ saturations (solid lines) and sea surface temperatures (dashed lines) during (a) leg SO119 and (b) leg SO120. For orientation, prominent stations and cruise features are marked (see Figure 1).

features of the SW monsoon triggered upwelling off Oman [Elliott and Savidge, 1990].

In the central Arabian Sea (Figure 2a) we observed no trend for the $\mathrm{CH}_{4}$ saturations. Even at station $\mathrm{P} 01$ when we touched the beginning of coastal upwelling, no increase in the $\mathrm{CH}_{4}$ saturations was detectable. In contrast, when we found a filament, a narrow band of upwelled water from the coast [Elliott and Savidge, 1990], centered approximately at $20.5^{\circ} \mathrm{N}, 60.5^{\circ} \mathrm{E}$, the $\mathrm{CH}_{4}$ concentrations during a 2-day survey were negatively correlated with sea surface temperatures. Maximum saturations (up to $145 \%$ ) were measured at station $\mathrm{K} 03\left(23.4^{\circ} \mathrm{N}, 60.1^{\circ} \mathrm{E}\right)$ located at the entrance to the Gulf of Oman. In the coastal upwelling area (Figure 2b), which was investigated during leg SO120 (June/July), we generally found elevated $\mathrm{CH}_{4}$ saturations associated with low sea surface temperatures. Maximum $\mathrm{CH}_{4}$ saturations (up to $156 \%$ ) were observed in the northern part of the coastal area. Enhanced $\mathrm{CH}_{4}$ values were also found during a drift study in the coastal upwelling (19-30 June, continued 4-7 July), whereas significantly lower saturations were observed at the transect to the central Arabian Sea (Figure 2b).

Figure 3 shows a plot of SST vs. $\mathrm{CH}_{4}$ concentration to illustrate the role of upwelling processes. With the exception of the data from station $\mathrm{K} 03$, high $\mathrm{CH}_{4}$ surface concentrations are associated with low SST. Interestingly, the regression lines are about the same for both the coastal upwelling and the filament, despite the fact that they are well separated features. The negative correlation between SST and $\mathrm{CH}_{4}$ concentrations might be due to the mixing of upwelled water masses with high $\mathrm{CH}_{4}$ concentrations and water masses from the central Arabian Sea with low $\mathrm{CH}_{4}$ concentrations. It seems that $\mathrm{CH}_{4}$ is formed in situ in the subsurface layer [Owens et al., 1991; Patra et al., 1998] and then brought to the surface in the course of upwelling events during the SW monsoon. As there was no indication from 


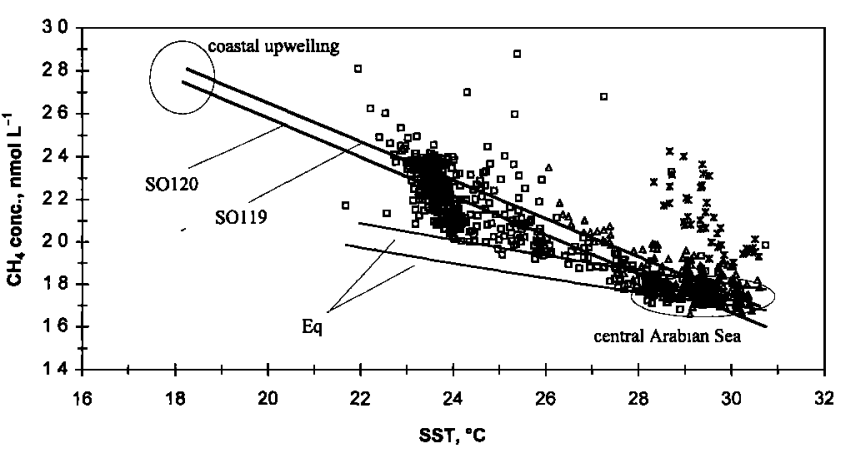

Figure 3. Dissolved $\mathrm{CH}_{4}$ concentration vs. sea surface temperature in the coastal northwestern Arabian Sea during the SW monsoon 1997. Open triangles indicate data from May/June (leg SO119), asterisks indicate data from station K03 (June, leg SO119), and open squares indicate data from June/July (leg SO120). Eq indicates the theoretical equilibrium concentrations calculated with mean atmospheric dry mole fractions of $1.7 \mathrm{ppm}$ and $1.8 \mathrm{ppm} \mathrm{CH}_{4}$, respectively. The parameters of the linear regressions are: $y=-0.090 x+4.446, r^{2}=0.62, n=539$ (SO119) and $y=-0.091 x+4.402, r^{2}=0.76, n=47$ (SO120); both correlations are significant at the $0.1 \%$ level. The two large circles indicate possible mixing endmembers at $28-31^{\circ} \mathrm{C}$ (central Arabian Sea) and $18{ }^{\circ} \mathrm{C}$ (upwelling) [Elliott and Savidge, 1990].

temperature data for upwelling at station $\mathrm{K} 03$ at the time of our measurements, these enhanced $\mathrm{CH}_{4}$ concentrations might result from $\mathrm{CH}_{4}$ enriched waters from the Gulf of Oman.

An overview of the mean saturations for various regions of the Arabian Sea is given in Table 1. The data from the central Arabian Sea are in very good agreement with data from the Pacific and Atlantic Oceans [Bates et al., 1996; Conrad and Seiler, 1988], but our saturation values are considerably lower than those published previously for the Arabian Sea. The first $\mathrm{CH}_{4}$ measurement from the Arabian Sea was reported by Lamontagne et al. [1973]. They measured $168 \%$ saturation in a single sample from the central Arabian Sea sampled in June 1967. Owens et al. [1991] reported for the central (on a transect along $67^{\circ} \mathrm{E}$ ) and northwestern Arabian Sea (i.e., the coastal upwelling area and the Gulf of Oman) an average $\mathrm{CH}_{4}$ surface saturation of $192 \pm 34 \%$ during the decline of the SW monsoon in September/October 1986. Recently, Patra et al. [1998] found in the central and eastern Arabian Sea mean values of $140 \pm 37 \%$, $173 \pm 54 \%$, and $200 \pm 74 \%$ in February/March 1995, April/May 1994, and July/August 1995, respectively. Summarizing the results from the various $\mathrm{CH}_{4}$ measurements in the Arabian Sea, we found substantial differences which might be partly caused by the interannual variability of the Arabian Sea and/or different spatial data coverage. For example, the data from Owens et al. [1991] are biased by the fact that 8 from 13 sampling stations were located in the $\mathrm{CH}_{4}$ enriched waters of the Gulf of Oman and in the upwelling influenced area off Oman.

We observed no overall seasonal trend for the central Arabian Sea (Table 1). A possible seasonality might be masked by the different area coverage of the cruises and by the scatter of the data for March as indicated by the relatively high standard deviation (Table 1). In contrast, Patra et al. [1998] found an overall seasonal shift of the $\mathrm{CH}_{4}$ saturations along $64^{\circ} \mathrm{N}$ from $96 \%$ (SW Monsoon) to $166 \pm 3 \%$ (Intermonsoon). Patra et al. [1998] argued that the observed undersaturation, which is based on two observations only, might be caused by downwelling and
$\mathrm{CH}_{4}$ oxidation. However, in the adjacent northern and southern areas Patra et al. [1998] found mean $\mathrm{CH}_{4}$ saturations in the range of 202 to $222 \%$, so that downwelling would lead to $\mathrm{CH}_{4}$ enrichment because of the subsequent horizontal transport of $\mathrm{CH}_{4}$ enriched water masses. Moreover, $\mathrm{CH}_{4}$ oxidation in oceanic surface waters is usually too slow to represent a significant sink for dissolved $\mathrm{CH}_{4}$ [Jones and Amador, 1993; Jones, 1991]. Filaments, characteristic features of the SW monsoon, show widths up to $150 \mathrm{~km}$ and can extend up to $400 \mathrm{~km}$ offshore from the coast of the Arabian Peninsula [Arnone et al., 1998]. As indicated by our data, they are able to transport $\mathrm{CH}_{4}$ enriched surface waters offshore (Figure 2a). Thus, filament structures lead to $\mathrm{CH}_{4}$ supersaturation than undersaturation in the central Arabian Sea during the SW monsoon. High surface saturations in the central Arabian Sea during the intermonsoon, as found by Patra et al. [1998], might be an indication of a considerable interannual variability of the Arabian Sea.

$\mathrm{CH}_{4}$ air-sea exchange. The $\mathrm{CH}_{4}$ exchange flux density, $F$ in pmol m${ }^{-2} \mathrm{~s}^{-1}$, can be parameterized as $F=k_{w}\left(C_{w}-C_{a}\right)$, where $k_{w}$ is the gas transfer coefficient, $C_{\tilde{w}}$ is the seawater concentration, and $C_{a}$ is the equilibrium water concentration calculated using the corresponding atmospheric dry mole fraction. To calculate $k_{w}$, we used the tri-linear $k_{w}$ /wind speed relationship from Liss and Merlivat [1986] (hereinafter referred to as LM86) or, alternatively, the quadratic $k_{w} /$ wind speed relationship established by Wanninkhof [1992] (hereinafter referred to as W92). The coefficients $k_{w}$ were adjusted by multiplying with $(S c / 600)^{-n}(n=$ $2 / 3$ for wind speeds $\leq 3.6 \mathrm{~m} \mathrm{~s}^{-1}$ and $n=0.5$ for wind speeds $>$ $\left.3.6 \mathrm{~m} \mathrm{~s}^{-1}\right)$ for LM86 and $(S c / 660)^{-05}$ for W92. Sc is the Schmidt number for $\mathrm{CH}_{4}$ and was calculated using empirical equations for the kinematic viscosity of seawater [Siedler and Peters, 1986] and the diffusivity of $\mathrm{CH}_{4}$ in water [Jahne et al, 1987]. The measured wind speeds were normalized to $10 \mathrm{~m}$ height by using the relationship of Garratt [1977]

In order to obtain an estimate of the annual $\mathrm{CH}_{4}$ emissions, we structured our data into those from the central Arabian Sea, the coastal upwelling areas, and the filament (i.e., open ocean upwelling) area. Then, we calculated mean flux densities and emissions for the three oceanographic regimes from the observed flux densities (Table 2). We assumed that our measurements are representative for the intermonsoon (Oct.-May) and SW monsoon (June-Sept.). By adding the seasonal emissions listed in Table 2, we obtain mean annual $\mathrm{CH}_{4}$ emissions in the range from 11 (LM86) to $20 \mathrm{Gg} \mathrm{CH}_{4}$ (W92). Our estimate is considerably lower than $\geq 40 \mathrm{Gg}$ and $30-50 \mathrm{Gg}$ of Owens et al. [1991] and Patra et al. [1998], respectively. Their higher estimates are the result of extrapolating high $\mathrm{CH}_{4}$ concentrations from upwelling areas. Extrapolation of our flux density data from the upwelling area (Table 2), using the area value of Owens et al. [1991] (1.56 x $10^{12} \mathrm{~m}^{2}$ ), which was also applied by Patra et al. [1998], indicates the annual emissions would be in the range of $13-22 \mathrm{Gg} \mathrm{CH}_{4}$.

Table 1. Mean $\mathrm{CH}_{4}$ Surface Saturations $(\% \pm 1 \sigma)$ in the Arabian Sea. The Numbers in Parenthesis Indicate the Number of Measurements.

March 1997 May/June 1997 June/July 1997

\begin{tabular}{lccc}
\hline Central Arabian Sea & $106 \pm 12(135)$ & $107 \pm 4(254)$ & $103 \pm 2(74)$ \\
Coastal upwelling & - & $107 \pm 2(6)$ & $116 \pm 8(463)$ \\
Filament & - & $113 \pm 5(46)$ & not measured \\
Entrance to Gulf of Oman not measured & $124 \pm 9(47)$ & $124 \pm 7(3)$
\end{tabular}


Table 2: Mean $\mathrm{CH}_{4}$ emissions from the Arabian Sea during 1997.

\begin{tabular}{lccc}
\hline & $\begin{array}{c}\text { Area }^{\mathrm{a}} \\
10^{12} \mathrm{~m}^{2}\end{array}$ & $\begin{array}{c}\text { Flux density } \\
\mathrm{pmol} \mathrm{m}^{-2} \mathrm{~s}^{-1}\end{array}$ & $\begin{array}{c}\text { Emissions } \\
\mathrm{Gg} \mathrm{CH}_{4}\end{array}$ \\
\hline $\begin{array}{l}\text { Intermonsoon } \\
\text { Arabian Sea (central + upwelling) }\end{array}$ & 7.0 & $2.0 / 3.7$ & $4.7 / 8.8$ \\
SW Monsoon & & & \\
Central Arabian Sea & 6.3 & $4.2 / 7.9$ & $4.5 / 8.4$ \\
Coastal Upwelling & 0.2 & $15.9 / 27.9$ & $0.5 / 0.9$ \\
Filaments & 0.5 & $12.3 / 21.6$ & $1.0 / 1.8$ \\
SUM (= annual mean) & & & $10.7 / 19.9$ \\
\hline
\end{tabular}

a Data taken from Körtzinger et al. [1997] (central Arabian Sea includes the Gulf of Oman).

${ }^{b}$ First value calculated according to Liss and Merlivat [1986]; second value calculated according to Wanninkhof [1992].

Although this is an overestimation due to neglect of seasonal variability, this value is still significantly lower than the previously published values. Our annual estimate $11-20 \mathrm{Gg} \mathrm{CH}_{4}$ (Table 2) exhibits three points of uncertainties: (1) we have no data from the Somali and the western Indian shelf upwelling, (2) we certainly overestimate the emissions for the open ocean upwelling areas because of the high temporal and spatial variability of filament structures, and (3) we caution that our estimate is based on data from two seasons within the same year and thus does not take into account the interannual variability of the Arabian Sea.

\section{Conclusions}

Summarizing the results of various $\mathrm{CH}_{4}$ measurements in the surface water of the Arabian Sea, we conclude that the considerable temporal and spatial variability of the hydrographic settings may lead to significant interannual differences and thus, complicates direct comparisons. The area-weighted, seasonally adjusted estimate of the annual $\mathrm{CH}_{4}$ emissions from the Arabian Sea (given in Table 2 ) suggests that previously reported very high surface concentrations are atypical and that the emissions derived from them are probably overestimates. The Arabian Sea, which covers $2 \%$ of the world's ocean area, may contribute about $0.1 \%$ to the global oceanic $\mathrm{CH}_{4}$ emissions, if Bange et al.'s [1994] estimate of $15 \mathrm{Tg} \mathrm{CH}_{4}$ for the global flux is used. On the other hand, the Arabian Sea's contribution, if we use Bates et al's [1996] estimate, would amount to $4 \%$ of the global flux. However, since the estimate of Bates et al. [1996] did not take into account coastal areas, we feel that it represents a considerable underestimation of the global oceanic source. Thus, we conclude that the role of coastal upwelling areas in the Arabian Sea for the global oceanic $\mathrm{CH}_{4}$ emissions is probably negligible.

Acknowledgments. We thank G. Schebeske and T. Kenntner for technical assistance and acknowledge the help of other colleagues, and the officers and crews of the R/V Sonne. Thanks are due to the chief scientists W. Balzer (SO117), V. Ittekkot (SO119), and B. Zeitzschel (SO120). Special thanks are due to T.S. Rhee, U. SchuBler, A. Deeken, and the team of the R/V Sonne scientific-technical service for their support on board. We thank C. Strametz for help with the manuscript. The investigations were financially supported by the German Bundesministerium für Bildung, Wissenschaft, Forschung und Technologie through Grant No. 03F0183G and by the Max Planck Society.

\section{References}

Arnone, R.A., R.W. Gould, J. Kindle, P. Martinolich, K. Brink, and C. Lee, Remote sensing of coastal upwelling and filaments off the coast of Oman (abstract), Oceanogr., 11 (No. 2 Supplement), 33, 1998.

Bange, H.W., U.H. Bartell, S. Rapsomanikis, and M.O. Andreae, Methane in the Baltic and North Seas and a reassessment of the marine emissions of methane, Global Biogeochem. Cycles, 8, 465$480,1994$.

Bates, T.S., K.C. Kelly, J.E. Johnson, and R.H. Gammon, A reevaluation of the open ocean source of methane to the atmosphere, $J$. Geophys. Res., 101, 6953-6961, 1996.

Cicerone, R.J., and R.S. Oremland, Biogeochemical aspects of atmospheric methane, Global Biogeochem. Cycles, 2, 299-327, 1988.

Conrad, R., and W. Seiler, Methane and hydrogen in seawater (Atlantic Ocean), Deep-Sea Res., 35, 1903-1917, 1988.

Elliott, A.J., and G. Savidge, Some features of the upwelling off Oman, $J$. Mar. Res., 48, 319-333, 1990.

Garratt, J.R., Review of the drag coefficients over oceans and continents, Mo Weath. Rev., 105, 915-929, 1977.

Hein, R., P.J. Crutzen, and M. Heimann, An inverse modeling approach to investigate the global atmospheric methane cycle, Global Biogeochem. Cycles, 11, 43-76, 1997.

Jahne, B., G. Heinz, and W. Dietrich, Measurements of the diffusion coefficients of sparingly soluble gases in water, $J$. Geophys. Res., 92, 10,767-10,776, 1987 .

Jones, R.D., Carbon monoxide and methane distribution and consumption in the photic zone of the Sargasso Sea, Deep-Sea Res., $38,625-635,1991$.

Jones, R.D., and J.A. Amador, Methane and carbon monoxide production, oxidation, and turnover times in the Caribbean Sea as influenced by the Orinoco River, J. Geophys. Res., 98, 2353-2359, 1993.

Kortzinger, A., L. Mintrop, and J.C. Duinker, Strong $\mathrm{CO}_{2}$ emissions from the Arabian Sea during the South-West Monsoon, Geophys. Res. Lett., 24, 1763-1766, 1997.

Lamontagne, R.A., J.W. Swinnerton, V.J. Linnenbom, and W.D. Smith, Methane concentrations in various marine environments, $J$. Geophys. Res., 78, 5317-5325, 1973.

Lelieveld, J., P.J. Crutzen, and C. Brahl, Climate effects of atmospheric methane, Chemosphere, 26, 739-768, 1993.

Liss, P.S., and L. Merlivat, Air-sea exchange rates: Introduction and synthesis, in The Role of Air-Sea Exchange in Geochemical Cycling, edited by P. Buat-Ménard, pp. 113-127, D. Reidel Publishing Company, Dordrecht, 1986.

Matthews, E., Assessment of methane sources and their uncertainties, Pure and Appl. Chem., 66, 154-162, 1994.

Owens, N.J.P., C.S. Law, R.F.C. Mantoura, P.H. Burkill, and C.A. Llewellyn, Methane flux to the atmosphere from the Arabian Sea, Nature, 354, 293-296, 1991.

Patra, P.K., S. Lal, S. Venkataramani, M. Gauns, and V.V.S.S. Sarma, Seasonal variability in distribution and fluxes of methane in the Arabian Sea, J. Geophys. Res., 103, 1167-1176, 1998.

Siedler, G., and H. Peters, Properties of sea water, in Oceanography, Landolt-Bornstein New Ser., Group V, vol. 3a, edited by J. Sündermann, pp. 233-264, Springer Verlag, New York, 1986.

Wanninkhof, R., Relationship between wind speed and gas exchange over the ocean, J. Geophys. Res., 97, 7373-7382, 1992.

Wiesenburg, D.A., and N.L. Guinasso Jr., Equilibrium solubilities of methane, carbon monoxide, hydrogen in water and seawater, $J$. Chem. Eng. Data, 24, 356-360, 1979.

M.O. Andreae and H.W. Bange, Max Planck Institute for Chemistry, Biogeochemistry Department, PO Box 3060, D-55020 Mainz, Germany. (e-mail: bange@mpch-mainz.mpg.de)

R. Ramesh, Institute for Ocean Management, Anna University, Chennai 600025 , India.

S. Rapsomanikis, Laboratory of Atmospheric Pollution Science and Technology, Department of Environmental Engineering, Demokritos University of Thrace, GR-67100 Xanthi, Greece.

(Received April 1, 1998; revised July 20, 1998;

accepted August 13, 1998) 